\title{
Effect of the Concentration of Hydrogen-Ion on the Flade Potential of Nickel*
}

\author{
By Go Okamoto** and Norio Sato**
}

\begin{abstract}
Electrochemical investigations have been made on the anodic passivily of nickel in acid and alkaline solutions. In addition to the Flade arrest $E_{2}$ observed previously, the other two definite arrests, $E_{1}$ and $E_{3}$, have been found on the potential decay curves; $E_{1}=+0.13-0.060 \mathrm{pH}, E_{2}=+0.48-0.060 \mathrm{pH}, E_{3}=+1.60-0.075 \mathrm{pH}(\mathrm{V})$. The observed potential $E_{1}$ is close to the theoretical redox potential of $\mathrm{Ni}+\mathrm{H}_{2} \mathrm{O} \rightleftarrows \mathrm{NiO}+2 \mathrm{H}^{+}+2 \mathrm{e}$, and $E_{3}$ is also nearly equal to the potential of $\mathrm{Ni}_{2} \mathrm{O}_{3}$ electrode measured in alkaline solution. Beyond the potential $E_{3}$, nickel was dissolved into the solution in the form of the trivalent ion. It was concluded that the Flade potential $E_{2}$ indicates the transformation potential from $\mathrm{NiO}$ to $\mathrm{Ni}_{3} \mathrm{O}_{4} ; 3 \mathrm{NiO}+\mathrm{H}_{2} \mathrm{O} \rightleftarrows \mathrm{Ni}_{3} \mathrm{O}_{4}+2 \mathrm{H}^{+}+2 \mathrm{e}$. Hence, the passivation of nickel in acid solution can be understood to reeult from the formation of the higher valence oxide of $\mathrm{Ni}_{3} \mathrm{O}_{4}$ or double oxide films of $\mathrm{NiO}$ and $\mathrm{Ni}_{3} \mathrm{O}_{4}$, but not to result from the formation of a single oxide film of $\mathrm{NiO}$.
\end{abstract}

(Received April 21, 1330)

\section{Introduction}

Since the day of Faraday many investigations have been conducted on the passivity of metals, but many unclarified problems have still remained on the mechanism of passivation. It has been known that if metal is polarized to more noble potentials progressively in a corrosive solution containing no reduction-oxidation system, the passivation occurs at a critical potential, and a well-defined potential arrest is of ten observed at this potential when the potential of metal is permitted to decay by switching off the passivating current. This potential arrest was first observed on passivated iron by Flade $(1)$ whose name it now bears. Since the Flade potential is one of the characteristic properties of the passivation of metals, it is desirable to understand the significance of this potential before discussing the mechanism of passivation.

Two different theories, both. the oxide film theory and the adsorption theory, have been previously proposed on the passivity of metals. According to the adsorption theory, Uhlig(2) has referred the Flade potential of iron to the equilibrium potential of the reaction $\mathrm{Fe}+\mathbf{n H}_{2} \mathrm{O} \rightarrow \mathrm{n} / 3 \cdot 0-\mathrm{O}_{2}$ (ads. on $\left.\mathrm{Fe}\right)+2 \mathrm{nH}^{+}$ $+2 \mathrm{n}$ e, where $0-\mathrm{O}_{2}$ designates the adsorption film on iron, and has shown a rough agreement between the thermodynamically calculated potential and the measured one. In the case of nickel, however, a considerable discrepancy between the two has been pointed out by the present authors. ${ }^{(3)(4)}$

The oxide film theory suggests that the Flade potential indicates an equilibrium potential of the formation of an oxide on metals which is given by

** Physico-chemical and Electrochemical Lab., Facully of Engineering, Hokkaido Universily, Sapporo.

* This paper was read at the general meeting of Japan Society of Electrochemistry held at Tokyo on November 23,1958 , and was written originally in Japanese in the Journal of the Japan Institute of Metals, 23 (1959), 662.

(1) F. Flade : Z. physik. Chem., 76 (1911), 513.

(2) H. H. Uhlig : Z. Elektrochem., 62 (1958), 626.

(3) G. Okamoto, T. Takaishi, N. Sato: J. Electrochem. Soc. Japan, $2 j$ (1958), 615 ; E. 188.

(4) G. Okamoto, N. Sato: J. Electrocher. Soc. Japan, 27 (1959), 321; E 125. the following basic reaction;

$$
\mathrm{Me}+\mathrm{nH}_{2} \mathrm{O} \rightleftarrows \mathrm{MeOn}+2 \mathrm{nH}^{+}+2 \mathrm{n} \mathrm{e}
$$

But, attempts to reconcile the measured value of the Flade potential with the free energies of formation for known bulk oxides have been unsuccessful for iron and nickel. In order to overcome this difficulty, several theories have been proposed.(3)(5)(6)(7)(8) In one of the concepts which is worth paying attention, a reaction giving rise to the Flade potential is assumed in the passive film based on the assumption of a double oxide film ${ }^{(7)(8)}$ or a single oxide film having non-uniform composition. ${ }^{(9)}$

All the above interpretations for the Flade potential have little experimental support. Considering that former experimental works were mainly restricted to the case of iron, the authors have made a series of experiments ${ }^{(4)(10)}$ on the passivity of nickel to find the two potential arrests on the decay curve of passive nickel, the more noble one of the two being ascertained to be the Flade potential.

The purpose of the present experimental work was to obtain more detailed information on the Flade potential of nickel. In order to find the potentialdetermining reaction at this potential, the effects of the concentration of hydrogen-ion upon the potential decay behavior of passive nickel have been investigated.

\section{Experimentals}

The specimen was prepared by electroplating. A nickel plate having a surface area of about $5 \mathrm{~cm}^{2}$ was welded to a platinum wire which was sealed into a glass tube, and the overall surface of the plate and the wire was electroplated with nickel at the current

(5) K. T. Vetter: Z. physik. Chem., 202 (1953), 1; N. F., 4 (1955), 165

(6) W. Schottky : Halbleiter Problem, II (1958), 233.

(7) H. Göhr, E. Lange : Z. Elektrochem., 61 (1957), 1291.

(8) G. H. Cartledge : Z. Elekırochem., 62 (1958), 684.

(9) M. J. Pryor : J. Electrochem. Soc., 106 (1959), 557.

(10) G. Okamoto, H. Kobayashi, M. Nagayama, N. Sato: Z. Eleklrochem., 62 (1958), 775. 
density of $10 \mathrm{~mA} / \mathrm{cm}^{2}$ at $40 \sim 50^{\circ} \mathrm{C}$ in a nickel sulfate bath $\left(\mathrm{NiSO}_{4}, 30 \mathrm{~g}: \mathrm{H}_{2} \mathrm{BO}_{3}, 3.8 \mathrm{~g}: \mathrm{H}_{2} \mathrm{O}, 10 \mathrm{cc}\right)$. The thickness of the electroplated film was $0.5 \sim 1 \mathrm{~mm}$. Electrolytic nickel of 99.9 per cent purity was used as an anode for electroplating and the sulfate bath was prepared from distilled water and A. R. grade reagents. The specimen was etched by a mixed acid solution of $50 \% \mathrm{H}_{2} \mathrm{SO}_{4}$ and $50 \% \mathrm{HNO}_{3}$ for about one minute and washed repeatedly with distilled water.

The solutions of various hydrogen-ion concentrations were made from A. $\mathrm{R}$. grade $\mathrm{H}_{2} \mathrm{SO}_{4}, \mathrm{~K}_{2} \mathrm{SO}_{4}, \mathrm{KOH}$ and distilled water, the concentration of the sulfate ion being adjusted to a constant value of $0.5 \mathrm{~m} \mathrm{SO} \mathrm{SO}_{4}^{2-}$ L. In order to increase the buffering action for the hydrogen-ion in the neutral region, small amounts of phosphate solution of $0.1 \mathrm{~m}\left(\mathrm{KH}_{2} \mathrm{PO}_{4}+\mathrm{K}_{2} \mathrm{HPO}_{4}\right) / \mathrm{L}$ was added to this sulfate soultion.

The closed type electrolytic cell schematically shown in Fig. 1 was used for the measurmet of the dissolution rate, oxygen-evolution rate and the potentialdecay curve. It has a capacity of $200 \mathrm{~mL}$, and was filled with the test solution. The other type of cell shown in the previous paper(10) was also used for the polarization measurement.

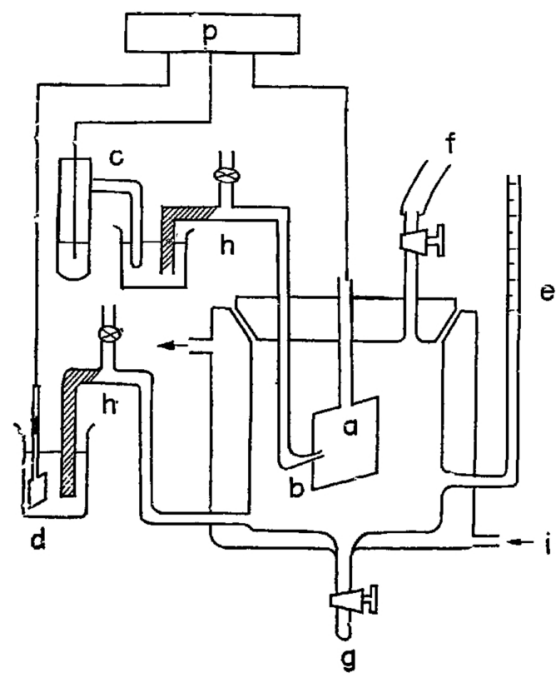

Fig. 1 Electrolytic cell $a=$ specimen, $b=$ capillary tip, $\mathbf{c}=$ saturated calomel reference electrode, $\mathrm{d}=$ auxiliary platinum electrode, $\mathrm{e}=$ measuring tube for gas evolution, $f=$ inlet for supplying the solution. $\mathrm{g}=$ outlet for sampling and exchanging the solutions, $\mathrm{h}=$ ager bridge, $i=$ inlet for supplying water of constant temperature, $\mathbf{p}=$ potentiostat.

The potential of the specimen was measured in reference to a saturated calomel electrode by a vacuum tube potentiometer, then it was converted into the value of the standard hydrogen scale. A potentiostat (the response, $10^{-2} \mathrm{sec}$ ) was used for the polarization of the specimen, and an electromagnetic oscillograph (d. c. sensitivity $2 \mu \mathrm{A}$, resonant frequency $150 \mathrm{c} / \mathrm{sec}$ ) was used for the measurment of the potential decay curve when necessary.

Dissolved oxygen and small amounts of oxidizing agents which affect the potential decay curve remarkably, were carefully removed by preliminary electrolysis with an auxiliary platinum cathode $\left(10 \mathrm{~cm}^{2}\right)$ for several hours at a current density of about $5 \mathrm{~mA} / \mathrm{cm}^{2}$ and by subsequent bubbling of pure nitrogen gas $\left(\mathrm{O}_{2}\right.$ $0.001 \%$ ) for one or two days before the experiment. All the experiments were carried out in a pure nitrogen atmosphere at a constant temperature of $25^{\circ} \mathrm{C}$.

The dissolution rate of nickel was determined by chemical analysis of a known amount of the solution taken out at fixed time intervals, by means of calorimetry with dimethylglyoxime as an indicator. The rate of oxygen evolution at N.T.P. was evaluated from the measured change of the solution head in the capilary tube (e in Fig. 1) which was open to the atmosphere.

\section{Results}

\section{(a) Valency of nickel ion in dissolution}

The stationary anodic polarization curve is shown in Fig. 2 for nickel in $1 \mathrm{n} \mathrm{H}_{2} \mathrm{SO}_{4}$ which was agitated thoroughly. The active-passive transition on the potentiostatic polarization takes place within the range from $+0.3 \sim+0.7$ volt, no definite transition potential being obtained by this method. The dissolution current $i$ is constant independently of the potential in the passive state (region A) and increases steeply with potential in the over-passive state (region B).

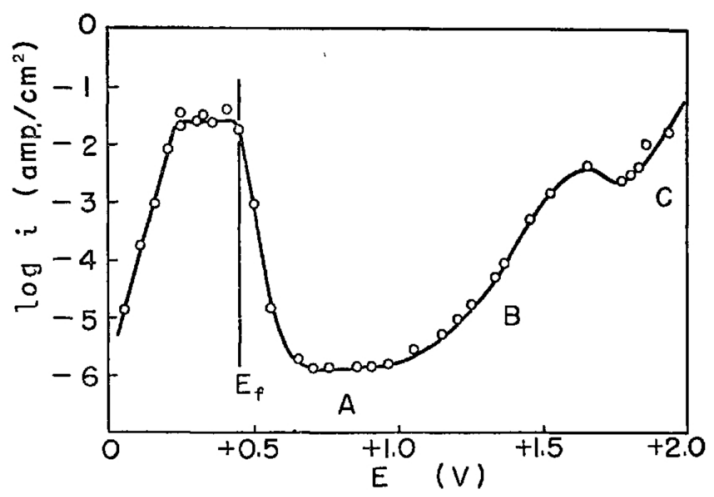

Fig. 2 Stationary potential-current curve of nickel obtained by a potentiostatic method. Electrolyte: $1 \mathrm{n} \mathrm{H}_{2} \mathrm{SO}_{4}$. Temperature: $25^{\circ} \mathrm{C}$.

The anodic evolution of oxygen gas was observed in the potential region $\mathrm{C}$. Under certain potentiostatic conditions, a current oscillation was observed during the transition from region $\mathrm{B}$ to region $\mathrm{C}$. This oscillation phenomenon suggests that the nature of the surfaces are different from each other in the two potential regions. (11)

The anodic current and the dissolution rate of nickel in the stationary state were measured at various potentials in the region A, B and C where the oxygen evolution rate was also measured at the same time. These results are tabulated in Table 1. Assuming that nickel dissolves into solution in the form of di-or trivalent nickel ion, the authors have evaluated the equivalent dissolution currents which are summarized in the 4 th column of Table 1. The divalent dissolution current is in a good agreement with the anodic current measured in regions $\mathrm{A}$ and $\mathrm{B}$. In region $\mathrm{C}$, if one assumes the trivalent dissolution, total equivalent

(11) U. F. Franck : Z. Elektrochem., 62 (1958), 649. 
Table 1 Anodic current, oxygen evolution rate and dissolution rate of the passive nickel in $1 \mathrm{n} \mathrm{H}_{2} \mathrm{SO}_{4}$ at $25^{\circ} \mathrm{C}$.

\begin{tabular}{|c|c|c|c|c|c|c|c|}
\hline \multirow{2}{*}{\multicolumn{2}{|c|}{ Potential region }} & Potential & \multirow{2}{*}{$\frac{\text { Dissolution rate }}{10^{-6} \mathrm{gx} / \mathrm{h}-\mathrm{cm}^{2}}$} & \multirow{2}{*}{\multicolumn{2}{|c|}{$\frac{\begin{array}{c}\text { Dissolution current } \\
\text { of } \mathrm{Ni}^{2+}\end{array}}{\mu \mathrm{A} / \mathrm{cm}^{2}}$}} & \multicolumn{2}{|c|}{ Observed anodic current } \\
\hline & & $V$ & & & & & $\mu \mathrm{A} / \mathrm{cm}^{2}$ \\
\hline \multicolumn{2}{|c|}{ A } & $\begin{array}{l}+0.750 \\
+0.800\end{array}$ & $\begin{array}{l}1.41 \\
1.46\end{array}$ & \multicolumn{2}{|c|}{$\begin{array}{l}1.29 \\
1.34\end{array}$} & & $\begin{array}{l}1.38 \\
1.40\end{array}$ \\
\hline \multicolumn{2}{|c|}{ B } & $\begin{array}{l}+1.150 \\
+1.200 \\
+1.390\end{array}$ & $\begin{array}{c}5.95 \\
11.2 \\
197\end{array}$ & \multicolumn{2}{|c|}{$\begin{array}{c}5.43 \\
10.2 \\
180\end{array}$} & & $\begin{array}{c}5.92 \\
10.5 \\
168\end{array}$ \\
\hline \multirow{2}{*}{$\begin{array}{c}\text { Potential } \\
\text { region }\end{array}$} & Potential & Dissolution rate & $\begin{array}{l}\text { Dissolution } \\
\text { current of } \mathrm{Ni}^{3}+\end{array}$ & $\begin{array}{l}\text { Equiv. current } \\
\text { of } \mathrm{O}_{2} \text { evolution }\end{array}$ & \multicolumn{2}{|c|}{$\begin{array}{l}\text { Total equiv. } \\
\text { current }\end{array}$} & $\begin{array}{c}\text { Observed } \\
\text { anodic current }\end{array}$ \\
\hline & $V$ & $10^{-6} \mathrm{gr} / \mathrm{h}-\mathrm{cm}^{2}$ & $\mu \mathrm{A} / \mathbf{c m}^{2}$ & $\mu \mathrm{A} / \mathrm{cm}^{2}$ & \multicolumn{2}{|c|}{$\mu \mathrm{A} / \mathrm{cm}^{2}$} & $\mu \mathrm{A} / \mathbf{c m}^{2}$ \\
\hline $\mathrm{C}$ & $\begin{array}{l}+1.775 \\
+1.800 \\
+1.830 \\
+1.870 \\
+1.930\end{array}$ & $\begin{array}{r}\overline{801} \\
1,030 \\
\overline{1,630}\end{array}$ & $\begin{array}{l}1, \overline{100} \\
1,420 \\
2, \overline{440}\end{array}$ & $\begin{array}{r}\overline{1,980} \\
2,910 \\
\overline{17,900}\end{array}$ & \multicolumn{2}{|c|}{$\begin{array}{r}3,080 \\
4,390 \\
20,100\end{array}$} & $\begin{array}{r}2,370 \\
3,150 \\
4,500 \\
11,600 \\
20,400\end{array}$ \\
\hline
\end{tabular}

current including dissolution and oxygen evolution is in a good agreement with the observed anodic current. The trivalent dissolution in region $\mathrm{C}$ was also supported by the fact that when potassium iodide was added, some free iodine which was produced as the result of the oxidation of the iodide ion due to the trivalent nickel ion, could be detected in the solution used for the experiment in region $\mathrm{C}$.

The partial equivalent currents are shown in Fig. 3 for both trivalent dissolution and oxygen evolution in

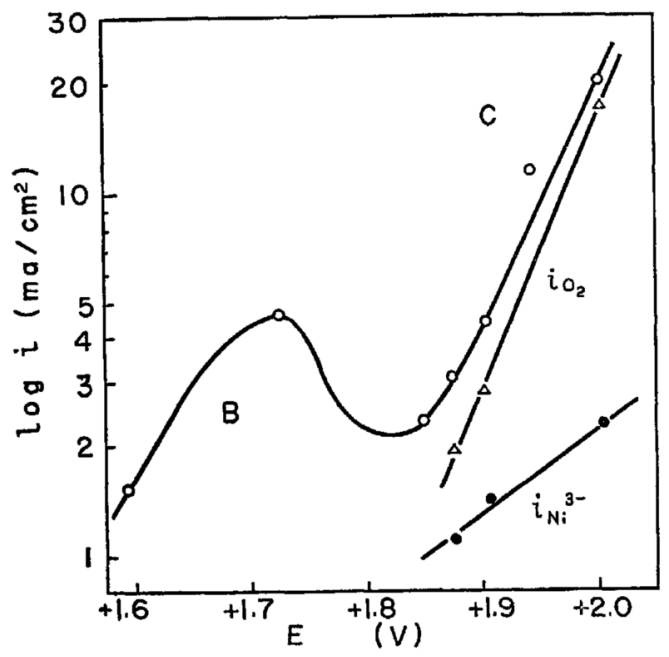

Fig. 3 Anodic current, oxygen evolution and dissolution of the passive nickel in $1 \mathrm{n} \mathrm{H}_{2} \mathrm{SO}_{4}$ at $25^{\circ} \mathrm{C}$. $i_{\mathrm{O} 2}$ : equivalent current of oxygen evolution. $i_{\mathrm{N}_{3} 3+}$ : equivalent current of dissolution of $\mathrm{Ni}^{3+}$.

region $\mathrm{C}$. The rate of trivalent dissolution in region $\mathrm{C}$ was smaller than that of divalent dissolution at the more noble potentials in region $B$, and its potential dependency was also different from that in region B.

\section{(b) Decay curve}

The potential decay curve of the passive nickel was measured in stationary acid solution after switching the anodic current off, the initial potential being maintained at a constant potential in region $A$ for about $30 \mathrm{hrs}$. The two potential arrests both $E_{2}$ and
$E_{1}$ were observed, two examples of which are shown in Fig. 4. It was confirmed in the previous paper(4) that the arrest potential $E_{2}$ is the Flade potential of passive nickel. Although the reproducibility in the arresting period of time is not necessarily good depending upon the initial condition of the specimen, especially upon the holding period of time at the initial potential, the both potential arrests are always recognized when the specimen is sufficiently aged for a long time in the initial passive state. When this aging period of time was short, no definite arrest was observed at the potential of $E_{2}$ as will be seen on the decay curve measured by some workers ${ }^{(12)}$ (curve 3 in Fig. 4.)

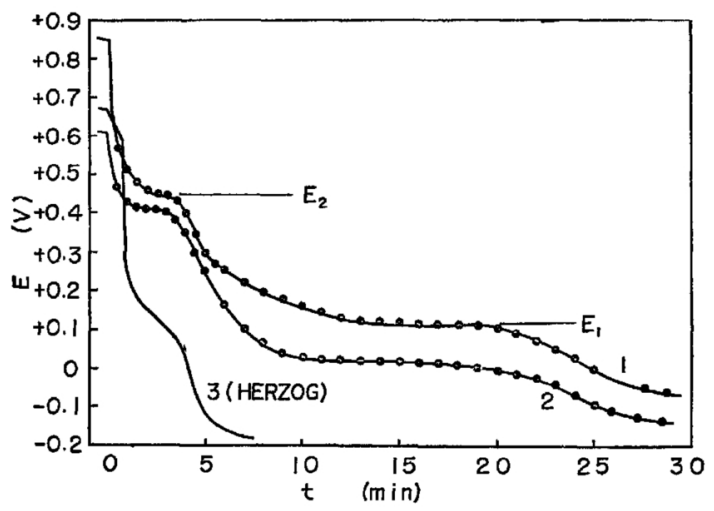

Fig. 4 Potential decay curves of passive nickel. 1: $1 \mathrm{n} \mathrm{H}_{2} \mathrm{SO}_{4} \cdot \mathrm{pH}=0.45$. 2: $1 \mathrm{~m} \mathrm{H}_{3} \mathrm{PO}_{4}, \mathrm{PH}=0.98$. 3: $1 \mathrm{n} \mathrm{H}_{2} \mathrm{SO}_{4}+0.1 \mathrm{n} \mathrm{NiSO}$, measured by $\mathrm{N}$. W. Herzog. (12)

In $1 \mathrm{n}$ acetic acid, no definite value for the two arrest potentials was estimated, becauce the observed potential arrests were not so clear as those obtained in sulfuric and in phosphoric acids, Such ambiguity for the arrest-potentials in organic acid solutions, which has already been recognized in the case of iron by Weil and Bonhoeffer, (13) may be caused by the

(12) N. W. Herzog : Prom. Nr. 2671, Eidgenögssischen Techn. Hochschule Zürich, (1957).

(13) K. G. Weil, K. F. Bonhoeffer : Z. physik. Chem. N. F., 4 (1955), 175. 
poisoning due to the adsorption of the organic anion.

When the potential of nickel was permitted to decay from a steady state in region $\mathrm{C}$, the other potential arrest was found at the more noble potential $E_{3}$ as is shown in Fig. 5 wbich was measured by electromagnetic oscillogram. A similar decaying bebavior from region $\mathrm{C}$ could also be observed in other acid solutions, both $1 \mathrm{~m} \mathrm{H}_{3} \mathrm{PO}_{4}$ and $1 \mathrm{~m} \mathrm{CH}_{3} \mathrm{COOH}$.

The above mentioned three potential arrests, $E_{1}$, $E_{2}$ and $E_{3}$, were recognized both in neutral and in alkaline solutions as well as in acid solutions, as are shown in Fig. 6. Only the least noble potential $E_{1}$ tends to approach the spontaneous potential, observed after $30 \mathrm{hrs}$, with the decrease of the hydrogen ion concentration.

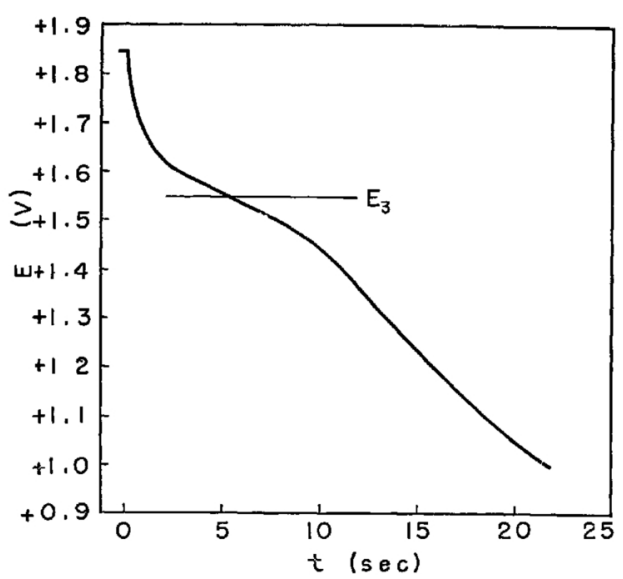

Fig 5 Potential decay curve of passive nickel from the potential of region $\mathrm{C}$.

Electrolyte: $1 \mathrm{n} \mathrm{H}_{2} \mathrm{SO}_{4}$. Temperature: $25^{\circ} \mathrm{C}$

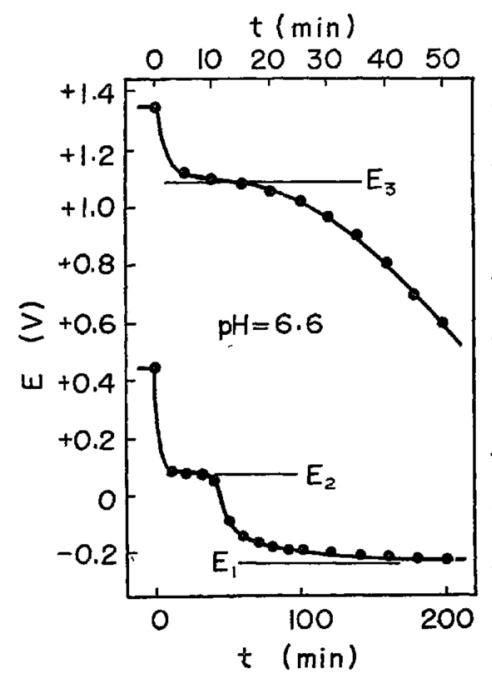

are given by

$$
\begin{aligned}
& E_{1}=+0.13-0.060 \mathrm{pH}(\mathrm{V}) \\
& E_{\bar{z}}=+0.48-0.060 \mathrm{pH}(\mathrm{V}) \\
& E_{3}=+1.60-0.075 \mathrm{pH}(\mathrm{V})
\end{aligned}
$$

The arrest potential $E_{3}$ estimated in alkaline region

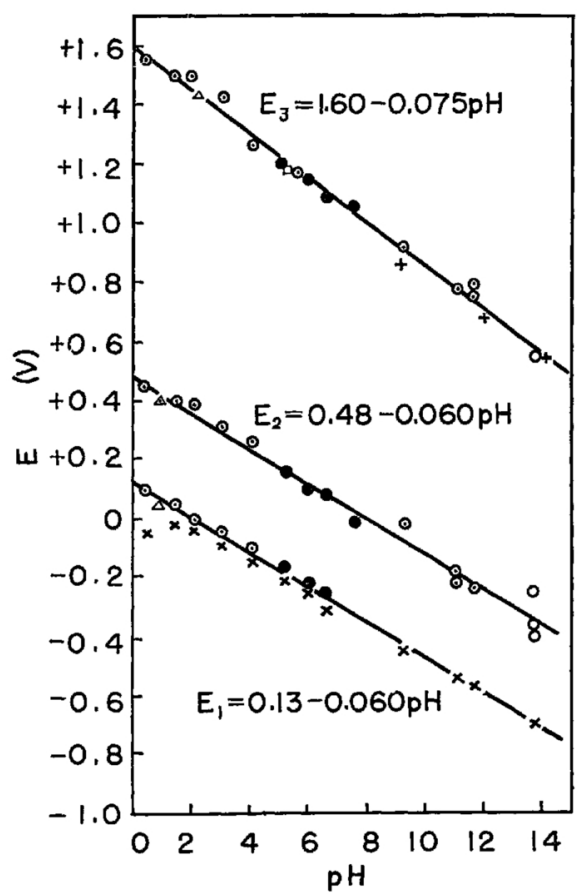

Fig. 7 Effect of $\mathrm{pH}$ on $E_{1}, E_{2}$, and $E_{3}$ at $25^{\circ} \mathrm{C}$

$x=$ spontaneous potential, $\odot=0.5 \mathrm{~m} \mathrm{SO}_{4}{ }^{2-}$,

- $=0.5 \mathrm{~m} \mathrm{SO}_{4}^{2-}+0.1 \mathrm{~m}\left(\mathrm{KH}_{2} \mathrm{PO}_{4}+\mathrm{K}_{2} \mathrm{HPO}_{4}\right)$,

$\triangle=0.5 \mathrm{~m} \mathrm{SO}_{4}+0.1 \mathrm{~m}\left(\mathrm{CH}_{3} \mathrm{COOH}+\mathrm{CH}_{3} \mathrm{COOK}\right)$,

$\Delta=1 \mathrm{~m} \mathrm{H}_{3} \mathrm{PO}_{4}, \mathrm{O}=1 \mathrm{n} \mathrm{KOH}$, + = values measured by Hickling and Spice. ${ }^{(13 a)}$

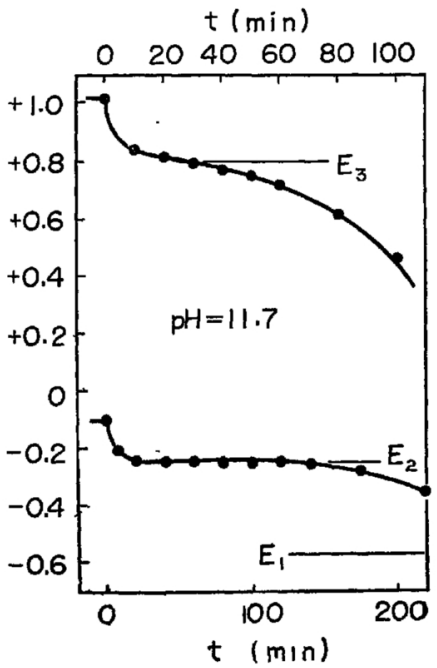

Fig. 6 Potential decay curves of passive nickel both in neutral and in alkaline solution at $25^{\circ} \mathrm{C}$

Electrolyte: $0.5 \mathrm{~m} \mathrm{Na}_{2} \mathrm{SO}_{4}+0.1 \mathrm{~m}\left(\mathrm{KH}_{2} \mathrm{PO}_{4}+\mathrm{K}_{2} \mathrm{HPO}_{4}\right), \mathrm{pH}=6.6 ; 0.5 \mathrm{~m}$ $\mathrm{Na}_{2} \mathrm{SO}_{4}+0.01 \mathrm{n} \mathrm{NaOH}, \mathrm{pH}=11.7$.

(c) Effect of the concentration of hydrogen ion

The three arrest potentials $\left(E_{1}, E_{2}\right.$ and $\left.E_{3}\right)$ and the spontaneous potential were estimated on the decay curve of nickel in sulfate solutions of various $\mathrm{pH}$ values from acid to alkaline regions. The results are shown in Fig. 7. All these potentials move towards the less noble direction with the increase of the concentration of the hydrogen ion; the $\mathrm{pH}$ dependencies is close to the potential of the $\mathrm{Ni}_{-} \mathrm{O}_{3}$ electrode reported by previous workers; some values measured by Hickling and Spice(13a) are shown in Fig. 7. In comparison with the results of the other workers, all the reported values of the Flade potential of nickel are shown in Fig. 8 together with the value estimated by the authors. 


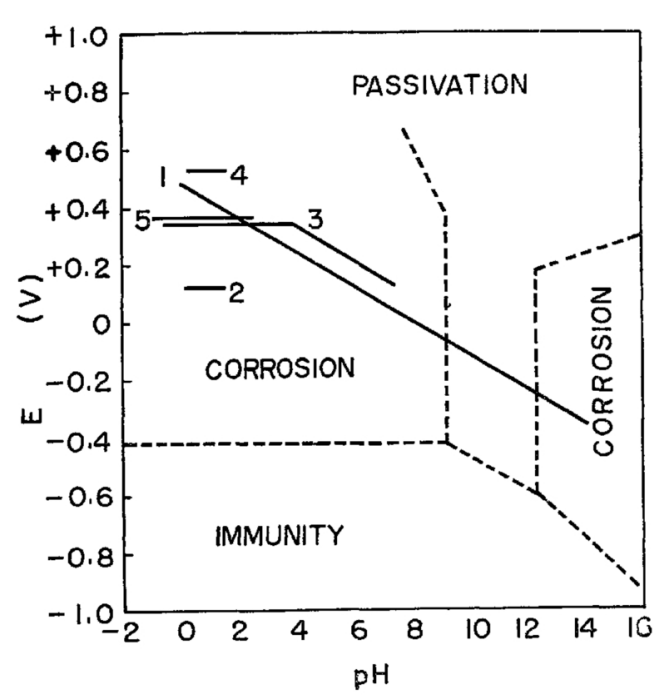

Fig. $8 \mathrm{pH}$ dependency of the Flade potential of nickel. 1: present experiment. 2: N. W. Herzog (12) 3: M. Pourtaix, N. Zoubov and E. Deltombe ${ }^{(16)}$ 4: D. R. Turner. (17) 5: V. Rothmond. (18) _- potential-pH diagram calculated by Pourbaix. (16)

\section{Discussions}

In the foregoing experiments, it was found that when the potential of the passive nickel was permitted to decay, the potential is arrested at the Flade potential $E_{2}$ and at the potential $E_{1}$ as well. Furthermore, the other arrest was found at the more noble potential $E_{3}$ in the potential decay starting from region $C$. These facts furnishes an important clue to the understanding of the Flade potential; from the relation in these three potentials, one can reasonably deduce the potentail determining reaction for the Flade potential.

In general, the observed potential of a metal immersed in a solution represents either an equilibrium potential of a single reduction-oxidation reaction or a mixed potential of several redox reactions. Within the potential range quoted here, two redox reactions, both the hydrogen- and the oxygen-electrode reaction, possibly exist thormodynamically in sulfate solutions. But, if there is no dissolved oxygen or hydrogen gas in the solution, no electrode reaction proceeds practically over the potential range from the equilibrium potential of oxygen electrode to that of the hydrogen electrode. In such a case, therefore, it may be assumed that the potential of a metal is determined by some redox reactions concerning either the metal itself or the surface film. It has widely been accepted that the arrest potential observed on the decay curve of a metal anode is closely related to the equilibrium potential of the surface oxide on the metal. This correlation between the two was verified in some cases with the negligible dissolution of the oxide film, for example $\mathrm{Ag} / \mathrm{KOH}^{(14)}$ and $\mathrm{Pb} / \mathrm{KOH} .{ }^{(14)}$ In the strictest meaning, the arrest potential on the decay curve does not indicate the equilibrium potential of the surface oxide film when the oxide film or the metal dissolves into the solution at an appreciable rate. An approximate

(14) E. Lange, K. Nagel : Z. physik. Chem., 110 (1924) 384 ; H. Göhr, E. Lange, Z. physik. Chem., 17 (1958), 100. coincidence of the two, however may be expected if the rate of the dissolution is comparably small as in the present case of the passive nickel in sulfate solution.

Three different types, $\mathrm{NiO}, \mathrm{Ni}_{3} \mathrm{O}_{4}$ and $\mathrm{Hi}_{2} \mathrm{O}_{3}$, have been known to exist in oxides of nickel, the existence of another type of $\mathrm{NiO}_{2}$ reported by several workers not being verified. In these three oxides, $\mathrm{NiO}$ is the only one that has the difinite thermodynamic values estimated from reliable experimental basis. The calculated equilibrium potential $E_{1}$ (calc) for the formation of $\mathrm{NiO}$

$$
\mathrm{Ni}+\mathrm{H}_{2} \mathrm{O} \underset{\leftarrow}{\mathrm{NiO}}+2 \mathrm{H}^{+}+2 \mathrm{e}
$$

is given by

$$
\begin{aligned}
E_{1}(\text { calc }) & =\frac{1}{2 F}\left(\mu_{\mathrm{Ni}}^{\circ}+2 \mu_{\mathrm{H}^{+}}^{\circ}-\mu_{\mathrm{Ni}}^{\circ}-\mu_{\mathrm{H}_{2} \mathrm{O}}^{\circ}\right)+\frac{R T}{2 F} \ln a_{\mathrm{H}^{+}} \\
& =+0.108-0.059 \mathrm{pH}\left(\mathrm{V}, 25^{\circ}\right)
\end{aligned}
$$

where $\mu^{\circ}$ designates the standard free energy of formation. (15) $E_{1}$ (calc), thus computed, is fairly close to the observed arrest potential $E_{1}$ shown by the formula (2). It can be therefore concluded that the arrest of $E_{1}$ is attributed to the redox reaction given by (3).*

From this conclusion it is naturally presumed that the arrests observed at the more noble potentials may correspond to the equilibrium potentials for the formation of the higher valeace oxides, and the formation affinities of which have not yet been accurately estimated.** The potential-determining redox reactions presumed by the authors for $E_{2}$ (Flade potential) and $E_{3}$ are as follows;

$$
\begin{aligned}
3 \mathrm{NiO} & +\mathrm{H}_{2} \mathrm{O}_{\leftarrow}^{\rightarrow} \mathrm{Ni}_{3} \mathrm{O}_{4}+2 \mathrm{H}^{+}+2 \mathrm{e} \\
E_{2}(\text { calc })= & \frac{1}{2 F}\left(\mu_{\mathrm{Ni}_{3} \mathrm{O}_{4}}^{\circ}+2 \mu_{\mathrm{H}^{+}}^{\circ}-3 \mu_{\mathrm{N}_{2} \mathrm{O}}^{\circ}-\mu_{\mathrm{H}_{2} \mathrm{O}}^{\circ}\right) \\
& -0.059 \mathrm{pH} \quad\left(\mathrm{V}, 25^{\circ}\right) \\
2 \mathrm{Ni}_{3} \mathrm{O}_{4} & +\mathrm{H}_{2} \mathrm{O} \underset{\leftarrow}{\rightleftarrows} 3 \mathrm{Ni}_{2} \mathrm{O}_{3}+2 \mathrm{H}^{+}+2 \mathrm{e} \\
E_{3}(\text { calc })= & \frac{1}{2 F}\left(3 \mu_{\mathrm{N}_{2} \mathrm{O}_{3}}^{\circ}+2 \mu_{\mathrm{H}^{+}}^{\circ}-2 \mu_{\mathrm{N}_{3} \mathrm{O}_{4}}^{\circ}-\mu_{\mathrm{H}_{2} \mathrm{O}}^{\circ}\right) \\
& -0.059 \mathrm{pH} \quad\left(\mathrm{V}, 25^{\circ}\right)
\end{aligned}
$$

These proposed reactions are supported by the following facts;

(a) Trivalent dissolution in region $\mathrm{C}$, and divalent dissolution in region A and B. A certain discrepancy observed between the transition potential from region B to region C (Fig. 3 ) and the arrest potential $E_{3}$ (Fig. 5) may have resulted from different observing conditions: one is measured in the dynamic state by

(15) W. M. Latimer: The Oxidation Potentials, New York, Prentic-Hall lnc., 1952.

* Within the accuracy of the present measurement, it would be difficult to draw a line between oxide and hydroxide.

** Standard free energies for the formation of both $\mathrm{Ni}_{3} \mathrm{O}_{4}$ and $\mathrm{Ni}_{2} \mathrm{O}_{3}$ have been calculated from the potential which was measured in $\mathrm{KOH}$ solution by Glemser and Einerhand.(19) But, their measurment is somewhat unreliable as was discussed in a separate paper (21).

(16) M. Pourbaix, N. de Zoubov, E. Deltombe : Compt. rend. de la 7 Reunion de C.I.T.G.E. Lindau. (1955), 193.

(17) D. R. Turner : J. Electrochem. Soc., 98 (1951), 434.

(18) V. Rothmond: Z. physik. Chem., 110 (1924), 384. 
using a potentiostat and the other is measured in the spontaneous state without the anodic current.

(b) $\mathrm{pH}$ dependencies of both $E_{2}$ and $E_{3}$. A little discrepancy $(0.075 \sim 0.059=0.0016 \mathrm{~V})$ recognized between the calculated $\mathrm{pH}$ dependency of the potential $E_{3}$ and the observed one, may be caused by the generation of another redox system involving $\mathrm{Ni}^{3+}$ ion produced in the solution layer just over the surface as the result of the trivalent dissolution, especially, in acid solution.

(c) A good agreement between the observed potential $E_{3}$ and the potential of $\mathrm{Ni}_{-} \mathrm{O}_{3}$ electrode measured in alkaline solution.

According to Glemser, Einerhand(19) and Feitknecht, ${ }^{(20)}$ the nickel oxides anodically formed in alkaline solution are indicated in the forms of $\mathrm{Ni}(\mathrm{OH}), \mathrm{Ni}_{3} \mathrm{O}_{2}$ $(\mathrm{OH})_{4}$ and $\beta-\mathrm{NiOOH}$, and have a lattice structure belonging to the same group of C- 6 hexagonal type. The structure of $\beta-\mathrm{NiOOH}$ is a stratified one, so called Arnfelt structure, and the structure of $\mathrm{Ni}_{3} \mathrm{O}_{2}(\mathrm{OH})_{4}$ is a similar one irregularly deformed which has a mean lattice constant larger than that of $\mathrm{Ni}(\mathrm{OH})_{2}$ and smaller than that of $\beta-\mathrm{NiOOH}$. From such similarity of the crystal structures, easy transformation would be expected in theze three oxides.

It is reasonably concluded from the above discussions that the Flade potential is not the formation potential of $\mathrm{NiO}$ as has been reported by some workers but the transformation potential from $\mathrm{NiO}$ to the higher valence oxide $\mathrm{Ni}_{3} \mathrm{O}_{4}$. Then, the passive oxide films seem to be composed of either the double oxide films of $\mathrm{NiO}$ and $\mathrm{Ni}_{3} \mathrm{O}_{4}$ or the single film of the higher valence oxide $\mathrm{Ni}_{3} \mathrm{O}_{4}$.

Finally, it should be pointed out that the passivation

(19) O. Glemser, J. Einerhand : Z. anorg. Chem., 261 (1950), 26; 43.

(20) W. Feitknechi, H. R. Christen, H. Studer : Z. anorg. Cherr., 283 (1956), 88 of nickel in acid solution does not result from the formation of a single oxide of $\mathrm{NiO}$ but the formation of the higher valence oxide of $\mathrm{Ni}_{3} \mathrm{O}_{4}$. One of the possible mechanism for the passivation of nickel, has already been proposed in the separate paper. ${ }^{(21)}$

\section{Summary}

The anodic behavior of nickel were investigated in acid and alkaline solutions to clarif $y$ the significance of the Flade potential. In addition to the Flade arrest, two other definite arrests were observed on the potential decay curve of nickel, the estimated potentials of which are as follows;

$$
\begin{aligned}
& E_{1}=+0.13-0.060 \mathrm{pH} \\
& E_{2}=+0.48-0.060 \mathrm{pH} \text { (Flade potential) } \\
& E_{3}=+1.60-0.075 \mathrm{pH}
\end{aligned}
$$

$E_{1}$ is fairly close to the theoretical equilibrium potential for the redox reaction, $\mathrm{Ni}+\mathrm{H}_{2} \mathrm{O} \rightleftarrows \mathrm{NiO}+2 \mathrm{H}^{+}+$ $2 \mathrm{e}$, and $E_{3}$ is in a good agreement with the potentid] of $\mathrm{Ni}_{2} \mathrm{O}_{3}$ electrode measured in alkaline solution.

Beyond the potential $E_{3}$ nickel was dissolved into solution in the form of trivalent ion. From these results it was concluded that the Flade potential was not the formation potential of $\mathrm{NiO}$ but the transformation potential from $\mathrm{NiO}$ to $\mathrm{Ni}_{3} \mathrm{O}_{4}$. The proposed redox reactions for $E_{2}$ and $E_{3}$ are respectively as follows;

$E_{2}$ (Flade potential),

$$
3 \mathrm{NiO}+\mathrm{H}_{2} \mathrm{O} \rightleftarrows \mathrm{Ni}_{3} \mathrm{O}_{4}+2 \mathrm{H}^{+}+2 \mathrm{e}
$$

$E_{3}$

$$
2 \mathrm{Ni}_{3} \mathrm{O}_{4}+\mathrm{H}_{2} \mathrm{O} \rightleftarrows 3 \mathrm{Ni}_{2} \mathrm{O}_{3}+2 \mathrm{H}^{+}+2 \mathrm{e} .
$$

(21) G. Okamoto, N. Sato: J. of Japan Inst. Metals, 24 (1960), 105.

(22) G. Okamoto, N. Sato : J. of Japan Inst. Metals, 23 (1959), 721. 